\title{
Pertanggungjawaban Hukum dan Perlindungan Hukum bagi Notaris dalam Membuat Party Acte
}

\author{
Vina Akfa Dyani \\ Magister Kenotariatan Fakultas Hukum Universitas Islam Indonesia \\ Jl. Cik Di Tiro No. 1 Yogyakarta \\ vhydeani@yahoo.co.id
}

\begin{abstract}
The main problem in this study is the first, how the legal liability by a Notary in making acte party, and secondly, how the legal protection for Notaries in making party acte. This research is a normative juridical research approach to law (statute approach). The data used is secondary data in the form of primary legal materials, secondary and tertiary. The results showed that there are 3 (three) forms of Notary legal responsibility in making acte party, namely the administrative responsibility, civil liability and criminal liability. Notary doing his duty in a responsible manner and in accordance with UUJN and other legislation, the right to protection of the law. Notary legal protection for agency basis given by the Honorary Council of Notaries and Notary Act laws and legal protection through the obligation / right of refusal Notary.
\end{abstract}

Keywords: Responsibility, Protection, Notary and Party Acte.

\begin{abstract}
Abstrak
Pokok permasalahan dalam penelitian ini adalah pertama, bagaimana pertanggungjawaban hukum oleh Notaris dalam membuat party acte, dan kedua, bagaimana perlindungan hukum bagi Notaris dalam membuat party acte. Peneltian ini merupakan penelitian yuridis normatif dengan pendekatan perundang-undangan (statute approach). Data yang digunakan adalah data sekunder yang berupa bahan hukum primer, sekunder dan tersier. Hasil penelitian menunjukkan bahwa terdapat 3 (tiga) bentuk tanggung jawab hukum Notaris dalam membuat party acte, yaitu tanggung jawab secara administratif, tanggung jawab perdata dan tanggung jawab pidana. Notaris yang melakukan tugas jabatannya secara bertanggung jawab dan sesuai dengan UUJN dan peraturan perundang-undangan lainnya, maka berhak mendapatkan perlindungan hukum. Perlindungan hukum bagi Notaris secara lembaga diberikan oleh Majelis Kehormatan Notaris dan secara peraturan perundang-undang Notaris mendapat perlindungan hukum melalui kewajiban/hak ingkar Notaris.
\end{abstract}

Kata-kata Kunci: Tanggung jawab, perlindungan, notaris dan party acte 


\section{Pendahuluan}

Notaris menurut Undang-Undang Nomor 2 Tahun 2014 tentang Perubahan atas Undang-Undang Nomor 30 Tahun 2004 tentang Jabatan Notaris (selanjutnya disebut UUJN) adalah pejabat umum yang berwenang untuk membuat akta autentik dan memiliki kewenangan lainnya sebagaimana dimaksud dalam Undang-Undang ini atau berdasarkan undang-undang lainnya. Berdasarkan definisi tersebut menurut Sjaifurrachman dapat disumpulkan bahwa wewenang Notaris sebagai Pejabat Umum membuat akta autentik, bersifat umum, sedangkan wewenang pejabat lainnya merupakan pengecualian, artinya wewenang itu tidak lebih dari pada pembuatan akta autentik yang secara tegas ditugaskan kepada mereka oleh undang-undang. ${ }^{1}$

Kewenangan Notaris dalam UUJN disebutkan pada Pasal 15. Kewenangan tersebut meliputi kewenangan untuk membuat Akta autentik mengenai semua perbuatan, perjanjian, dan penetapan yang diharuskan oleh peraturan perundang-undangan dan/atau yang dikehendaki oleh yang berkepentingan untuk dinyatakan dalam Akta autentik (Pasal 15 ayat (1)). Kewenangan lainnya diatur lebih lanjut di dalam Pasal 15 ayat (2) dan ayat (3) UUJN.

Akta autentik menurut kamus hukum adalah akta yang sejak awal dibuat dengan sengaja dan resmi untuk pembuktian apabila terjadi sengketa di kemudian hari. ${ }^{2}$ Akta autentik menurut Pasal 1868 Kitab Undang-Undang Hukum Perdata (KUH Perdata) adalah suatu akta yang dibuat dalam bentuk yang ditentukan undang-undang oleh atau dihadapan pejabat umum yang berwenang untuk itu di tempat akta itu dibuat. Berdasar definisi akta autentik menurut Pasal 1868 KUH Perdata tersebut maka dapat diketahui bahwa ada 2 (dua) bentuk akta autentik yaitu akta yang dibuat oleh pejabat umum yang berwenang (disebut sebagai akta pejabat/ambtelijke acte) dan akta yang dibuat di hadapan pejabat umum yang berwenang (disebut sebagai party acte/akta para pihak).

Menurut Sjaifurrachman, perbedaan sifat dua macam akta itu adalah sebagai berikut: "Dalam akta pejabat (ambtelijke acte atau verbal acte), akta ini masih sah sebagai suatu alat pembuktian apabila ada satu atau lebih di antara penghadapnya tidak menandatangani akta, sepanjang Notaris menyebutkan alasan pihak yang tidak menandatangani akta tersebut,"3 sedangkan tidak ditandatanganinya akta di dalam party acte akan menimbulkan akibat yang hlm. 63.

${ }^{1}$ Sjaifurrachman, Aspek Pertanggungjawaban Notaris dalam Pembuatan Akta, (Bandung: Mandar Maju, 2011),

${ }^{2}$ M. Marwan \& jimmy P., Kamus Hukum (Dictionary of Law Complete Edition), Cetakan Kesatu, (Surabaya: Reality Pulisher, 2009), hlm. 31.

3Sjaifurrachman, ... op. cit., hlm. 109. 
lain. Apabila salah satu pihak tidak membubuhkan tanda tangannya dalam party acte maka dapat diartikan pihak tersebut tidak menyetujui isi akta yang dibuatnya, kecuali apabila tidak menandatangani akta itu didasarkan atas alasan yang kuat. Alasan yang dapat diterima untuk tidak membubuhkan tanda tangan di dalam party acte. Alasan-alasan pihak yang tidak dapat membubuhkan tanda tangannya tersebut harus dicantumkan dengan jelas oleh Notaris dalam akta yang bersangkutan. ${ }^{4}$

Notaris berwenang untuk membuat akta autentik mengenai perbuatan hukum para penghadap sepanjang tidak bertentangan dengan peraturan perundang-undangan yang berlaku. Berdasar kewenangan tersebut, maka memunculkan tanggung jawab bagi Notaris untuk melaksanakan perintah undang-undang. Notaris bertanggung jawab mematuhi peraturan perundang-undangan dalam hal pelaksanaan tugas jabatannya, oleh karena itu berdasar tanggung jawab Notaris yang besar terutama dalam membuat party acte yang berhubungan langsung dengan kepentingan para penghadap, maka Notaris perlu untuk mendapatkan perlindungan hukum.

Berdasar uraian di atas, karena jabatan Notaris mempunyai peran yang sangat penting, maka perlu untuk dikaji secara proporsional (seimbang) antara tanggung jawab hukum Notaris dan perlindungan hukum bagi Notaris dalam melaksanakan tugas jabatannya untuk membuat party acte.

\section{Rumusan Masalah}

Berdasarkan uraian di atas, maka dapat ditarik 2 (dua) poin rumusan masalah yaitu; pertama, bagaimana pertanggungjawaban hukum Notaris dalam membuat party acte?; dan kedua, bagaimana perlindungan hukum bagi Notaris dalam membuat party acte?

\section{Tujuan Penelitian}

Kajian dalam penelitian ini bertujuan untuk mengetahui bagaimana pertanggungjawaban hukum oleh Notaris dalam membuat party acte dan mengetahui bentuk-bentuk perlindungan hukum bagi Notaris dalam membuat party acte.

\section{Metode Penelitian}

Peneltian ini merupakan penelitian yuridis normatif dengan pendekatan perundangundangan (statute approach). Data yang digunakan adalah data sekunder yang berupa bahan hukum primer, bahan hukum sekunder dan dan bahan hukum tersier. Pengumpulan bahan 
hukum untuk penelitian ini menggunakan teknik Studi Dokumen. Yaitu melakukan penelitian terhadap dokumen-dokumen yang erat kaitannya dengan objek penelitian guna mendapatkan landasan teoritis dan memperoleh informasi dalam bentuk ketentuan formal dan melalui naskah resmi yang ada. Bahan yang terkumpul akan dianalisis secara kualitatif dan disajikan dalam bentuk deskriptif.

\section{Hasil Penelitian dan Pembahasan}

\section{Tanggung Jawab Hukum Notaris dalam Membuat Party Acte}

Tanggung jawab berdasarkan definisi dari responsibility adalah kewajiban bertanggungjawab atas undang-undang yang dilaksanakannya dan memperbaiki kerusakan yang ditimbulkannya. Tanggung jawab yang dibebankan kepada Notaris menurut penulis tepat untuk menggunakan istilah responsibility ini. Responsibility mempunyai makna yang merujuk kepada tanggung jawab Notaris untuk melaksanakan jabatannya atas perintah undang-undang, dan Notaris juga bertanggung jawab untuk memberikan ganti rugi atas kesalahan yang dilakukan, bilamana kesalahan tersebut menimbulkan kerugian bagi pihak yang menghadap kepada Notaris atau pihak lain yang bersangkutan.

Tanggung jawab Notaris dalam melaksanakan jabatannya dapat diartikan bahwa Notaris wajib melaksanakan ketentuan-ketentuan di dalam Undang-Undang Nomor 2 Tahun 2014 tentang Perubahan atas Undang-Undang Nomor 30 Tahun 2004 tentang Jabatan Notaris (selanjutnya disebut UUJN). Notaris bertanggung jawab untuk melaksanakan kewenangan sesuai dengan Pasal 15 UUJN, melaksanakan kewajiban Notaris berdasar Pasal 16 UUJN dan membuat akta autentik (akta Notaris) sesuai dengan ketentuan Bab VII UUJN tentang Akta Autentik.

Notaris di samping wajib mematuhi segala peraturan yang terdapat di dalam UUJN, juga wajib mematuhi kode etik Notaris. Notaris sebagai sebuah profesi memerlukan adanya kode etik yang mengatur perilaku Notaris dalam melaksanakan tugas jabatannya. Profesi Notaris perlu diatur dengan kode etik karena sifat dan hakikat dari pekerjaan Notaris yang sangat berorientasi pada legalisasi, sehingga dapat menjadi fundamen hukum utama tentang status harta benda, hak, dan kewajiban seorang klien yang menggunakan jasa Notaris tersebut. ${ }^{5}$ Tanggung jawab Notaris terhadap kode etik Notaris ini dapat dinamakan dengan tanggung jawab moral atau perilaku pejabat Notaris. Kode etik Notaris dirumuskan oleh

${ }^{5}$ Munir Fuady, Profesi Mulia (Etika Profesi Hukum bagi Hakim, Jaksa, Advokat, Notaris, Kurator, dan Pengurus), Cetakan Pertama, (Bandung: PT. Citra Aditya Bakti, 2005), hlm. 133. 
Organisasi Notaris yaitu Ikatan Notaris Indonesia (INI) sebagaimana diatur oleh ketentuan Pasal 82 UUJN. Pengawasan terhadap Notaris dalam melaksanakan kode etik Notaris dilakukan oleh Dewan Kehormatan Notaris sebagaimana diatur di dalam Pasal 1 angka 8 huruf a Kode Etik Notaris.

Konsep tanggung jawab juga dikemukakan oleh pencetus teori hukum murni yaitu Hans Kelsen. Menurut Hans, tanggung jawab berkaitan erat dengan kewajiban, namun tidak identik. Kewajiban tersebut muncul karena adanya aturan hukum yang mengatur dan memberikan kewajiban kepada subyek hukum. Subyek hukum yang dibebani kewajiban harus melaksanakan kewajiban tersebut sebagai perintah dari aturan hukum. Akibat dari tidak dilaksanakannya kewajiban maka akan menimbulkan sanksi. Sanksi ini merupakan tindakan paksa dari aturan hukum supaya kewajiban dapat dilaksanakan dengan baik oleh subyek hukum. Menurut Hans, subyek hukum yang dikenakan sanksi tersebut dikatakan "bertanggung jawab" atau secara hukum bertanggung jawab atas pelanggaran. ${ }^{6}$

Berdasar konsep tersebut, maka dapat dikatakan bahwa tanggung jawab muncul dari adanya aturan hukum yang memberikan kewajiban kepada subyek hukum dengan ancaman sanksi apabila kewajiban tersebut tidak dilaksanakan. Tanggung jawab demikian dapat juga dikatakan sebagai tanggung jawab hukum, karena muncul dari perintah aturan hukum/undang-undang dan sanksi yang diberikan juga merupakan sanksi yang ditetapkan oleh undang-undang, oleh karena itu pertanggungjwaban yang dilakukan oleh subyek hukum merupakan tanggung jawab hukum.

Konsep tanggung jawab tersebut berlaku terhadap Notaris. Menurut peraturan perundang-undangan yaitu UUJN, Notaris merupakan subyek hukum yang dibebani kewajiban sebagaimana diatur di dalam Pasal 16 UUJN. Notaris wajib melaksanakan kewajibannya sesuai dengan perintah UUJN, jika tidak maka Notaris akan dikenai sanksi sebagaimana diatur dalam Pasal 16 ayat (11), ayat (12) dan ayat (13) UUJN. Notaris yang dikenai sanksi atas pelanggaran yang dilakukan maka Notaris tersebut bertanggung jawab untuk melaksanakan sanksi sebagaimana diatur oleh UUJN.

Notaris dalam membuat party acte harus memperhatikan ketentuan BAB VII UUJN tentang Akta Notaris. Pasal 38 UUJN menguraikan ketentuan mengenai syarat sah sebuah Akta Notaris berdasarkan bentuknya harus terdiri dari awal akta atau kepala akta, badan akta, dan akhir atau penutup akta, masing-masing dari bagian akta tersebut dijelaskan secara rinci di dalam ayat (2), ayat (3) dan ayat (4) Pasal 38 UUJN. Ketentuan mengenai syarat sah

${ }^{6}$ Hans Kelsen, Pure Theory of Law, Terjemah, Raisul Muttaqien, Teori Hukum Murni: Dasar-Dasar Imu Hukum Normatif, Cetakan Keenam, Bandung: Penerbit Nusa Media, 2008, hlm. 136. 
sebuah akta Notaris kemudian dijelaskan oleh UUJN tidak hanya terhadap bentuk akta saja, akan tetapi ketentuan mengenai kecakapan para pihak yang menghadap juga menjadi suatu kewajiban untuk sebuah akta notariil dianggap sah dan mengikat para pihak yang membuatnya.

Ketentuan mengenai keabsahan akta Notaris diatur dalam Pasal 38, Pasal 39 dan Pasal 40 UUJN. Ketentuan tersebut harus dipenuhi oleh Notaris dalam membuat akta, karena Pasal 41 mengatur bahwa apabila ketentuan-ketentuan tersebut tidak dipenuhi maka mengakibatkan Akta hanya mempunyai kekuatan pembuktian sebagai akta di bawah tangan. Tanggung jawab Notaris untuk melaksanakan ketentuan UUJN dalam hal ini adalah mutlak. Notaris yang melanggar ketentuan UUJN yang mengakibatkan akta para pihak hanya mempunyai kekuatan pembuktian sebagai akta di bawah tangan maka dapat menjadi dasar para pihak yang merasa dirugikan untuk menuntut ganti kerugian dan bunga kepada Notaris yang bersangkutan. Ketentuan lebih lanjut mengenai keabsahan akta Notaris diatur oleh Pasal 42, Pasal 43, Pasal 44, Pasal 45, Pasal 46, Pasal 47, Pasal 48, Pasal 49, Pasal 50, Pasal 51, Pasal 52, dan Pasal 53 UUJN.

Berdasar keterkaitan antara tanggung jawab, kewajiban dan sanksi menurut teori Hans Kelsen dan terhadap kewenangan, kewajiban dan keautentikan akta Notaris berdasarkan UUJN, maka dapat diuraikan bahwa tanggung jawab hukum Notaris dalam membuat party acte dapat dibagi menjadi 3 (tiga) bentuk tanggung jawab, yaitu: tanggung jawab administratif, tanggung jawab perdata, dan tanggung jawab pidana oleh Notaris.

\section{Tanggung Jawab Hukum Notaris secara administratif}

Tanggung jawab hukum Notaris dalam membuat party acte secara administratif dapat dilihat dari bentuk sanksi yang diberikan atas pelanggaran terhadap kewajiban yang dibebankan kepada Notaris. Pasal 16 ayat (11) menyatakan sanksi berupa: peringatan tertulis; pemberhentian sementara; pemberhentian dengan hormat; atau pemberhentian dengan tidak hormat. Sanksi-sanksi tersebut diberikan apabila Notaris melanggar ketentuan Pasal 16 ayat (1) huruf a sampai dengan 1 sehubungan dengan tugas Notaris dalam membuat party acte. Sifat sanksi pada ayat tersebut menurut pendapat penulis adalah sanksi yang bersifat administratif. Pendapat tersebut didasarkan pada pendapat J.B.J.M. ten Berge sebagaimana dikutip oleh Habib Adjie, bahwa sanksi administratif dapat dibedakan menjadi 3 (tiga) macam, yaitu: ${ }^{7}$

7 Habib Adjie, Sanksi Perdata dan Administratif terhadap Notaris sebagai Pejabat Publik, Cetakan Kedua, Bandung: Refika Aditama, 2009, hlm. 106-107. 
1) Sanksi reparatif, yaitu sanki yang ditujukan untuk perbaikan atas pelanggaran tata tertib hukum. Sanksi kepada Notaris berupa peringatan tertulis merupakan sanksi administratif yang bersifat reparatif. Notaris diberikan peringatan tertulis bertujuan agar Notaris dapat memperbaiki kesalahan yang dilakukanya sehingga Notaris dapat melaksanakan jabatannya secara tertib hukum. Sanksi berupa peringatan yang diberikan kepada Notaris tidak menghalangi kewenangan Notaris dalam membuat akta autentik, artinya Notaris yang diberi sanksi berupa peringatan tertulis dapat tetap menjalankan jabatannya, namun harus memperbaiki kesalahan dan bertindak hati-hati sehingga kesalahan/pelanggaran tersebut tidak terulang.

2) Sanksi punitif, yaitu sanksi yang bersifat menghukum, dan hukuman tersebut merupakan beban tambahan. Sanksi berupa pemberhentian sementara kepada Notaris merupakan sanksi yang bersifat punitif. Pemberhentian sementara dianggap sebagai hukuman bagi Notaris karena telah melakukan pelanggaran terhadap kewajiban yang dibebankan kepadanya. Notaris yang mendapatkan sanksi ini tidak dapat menjalankan jabatannya untuk sementara waktu (dalam kurun waktu yang ditentukan oleh pihak yang memberikan sanksi), dan dapat menjalankan jabatannya lagi apabila waktu hukuman telah berakhir. Pemberhentian sementara ini bertujuan agar Notaris yang bersangkutan dapat berfikir dan lebih berhati-hati dalam menjalankan tugas jabatannya ketika hukuman tersebut berakhir.

3) Sanksi Regresif, yaitu sanksi sebagai reaksi dari tindakan tidak taat, yang berakibat dicabutnya hak atas sesuatu yang diputuskan menurut hukum, seolah-olah dikembalikan kepada keadaan hukum yang sebenarnya sebelum keputusan diambil. Sanksi berupa pemberhentian dengan hormat dan pemberhentian dengan tidak hormat kepada Notaris merupakan sanksi yang bersifat regresif. Notaris yang sudah menjalankan jabatanya karena melakukan pelanggaran, kemudian dicabut jabatannya tersebut dan dikembalikan kepada keadaan semula yaitu sebelum adanya Surat Keputusan pengangkatan Notaris dari Menteri. Sanksi ini tentu saja diberikan kepada Notaris yang telah melakukan pelanggaran yang berat, sehingga berakibat dicabutnya jabatan Notaris yang melekat pada subyek hukum tersebut.

\section{Tanggung Jawab Hukum Notaris secara Perdata}

Notaris dalam membuat party acte bertanggung jawab secara perdata dengan melihat sanksi yang diberikan kepada Notaris merupakan sanksi perdata. Ketentuan Pasal 16 ayat (12) memberikan tanggung jawab Notaris secara perdata kepada pihak yang menghadap kepada Notaris. Ketentuan tersebut berbunyi, bagi Notaris yang melakukan pelanggaran kewajiban Notaris Pasal 16 ayat (1) huruf j terkait party acte dapat dikenai sanksi berupa penggantian biaya, ganti rugi, dan bunga kepada Notaris. Sanksi tersebut dapat dijatuhkan bersamaan dengan sanksi administratif yang telah diuraikan di atas. Berbeda dengan sanksi administratif, sanksi yang diberikan oleh ayat (12) ini merupakan sanksi perdata, karena memungkinkan untuk Notaris memberikan ganti rugi dan bunga yang identik dengan ketentuan dalam hukum perdata kepada pihak yang merasa dirugikan.

Ketentuan mengenai sanksi perdata terhadap Notaris juga terlihat pada ketentuan Pasal 44 ayat (5) UUJN. Notaris yang melanggar ketentuan sebagaimana dimaksud pada 
ayat (1), ayat (2), ayat (3) dan ayat (4) Pasal 44 UUJN dapat dituntut ganti rugi dan bunga oleh pihak yang karena kelalaian Notaris pihak tersebut menderita kerugian. Pasal 41 UUJN juga memuat ketentuan mengenai kebatalan akta Notaris apabila tidak memenuhi ketentuan Pasal 38, Pasal 39, dan Pasal 40 tentang bentuk, kedudukan cakap bertindak para pihak serta saksi dalam membuat akta Notaris. Akta Notaris yang hanya mempunyai kekuatan pembuktian sebagai akta di bawah tangan akibat Notaris tidak membuat akta sesuai ketentuan UUJN tentu saja mempengaruhi kepentingan para pihak yang menghadap kepada Notaris, mengingat bahwa akta Notaris merupakan akta autentik dan memiliki nilai pembuktian yang sempurna. Meskipun di dalam Pasal 41 UUJN tida memuat ketentuan bahwa para pihak dapat menuntut ganti rugi dan bunga, namun apabila para pihak menderita kerugian akibat akta yang dibuat di hadapan Notaris hanya berlaku sebagai akta di bawah tangan (bukan akta auentik) maka menurut kaca mata hukum perdata, hal tersebut dapat dijadikan alasan untuk para pihak menuntut ganti kerugian kepada Notaris yang bersangkutan. Notaris dalam hal ini wajib bertanggung jawa secara perdata terhadap para pihak yang merasa dirugikan.

Pasal 1243 KUH Perdata memberikan ketentuan bahwa pihak yang lalai untuk memenuhi suatu perikatan maka dapat dituntut oleh pihak yang merasa dirugikan atas tidak dipenuhinya prestasi dalam perikatan tersebut, tuntutan tersebut antara lain; ganti rugi berupa penggantian biaya-biaya dan kerugian yang diderita serta keuntungan yang seharusnya diperoleh. Notaris sebagai pihak yang diwajibkan oleh ketentuan Pasal 16 ayat (1) huruf j, Pasal 38, Pasal 39, Pasal 40, Pasal 42 dan Pasal 43 UUJN dapat dikatakan sebagai subyek hukum yang wajib melaksanakan prestasi. Prestasi yang harus dipenuhi oleh Notaris adalah membuat akta autentik berdasar ketentuan UUJN, dan subyek hukum yang berhak atas akibat baik/keuntungan dari dilaksanakannya prestasi tersebut adalah pihak yang menghadap kepada Notaris (klien Notaris). Apabila pihak yang menghadap kepada Notaris merasa dirugikan karena Notaris tidak melaksanakan kewajibannya sesuai dengan ketentuan di dalam UUJN, maka penghadap dapat menuntut kepada Notaris berupa penggantian biayabiaya yang telah dikeluarkan, ganti kerugian dan bunga atau keuntungan yang seharusnya diperoleh. Tanggung jawab Notaris yang demikian itu disebut dengan tanggung jawab perdata.

Sanksi ini diberikan kepada Notaris apabila Notaris melakukan pelanggaran yang mengakibatkan kerugian oleh pihak yang menghadap atau meminta bantuan jasa kepada Notaris, sehingga akibat dari kerugian tersebut dapat menjadi alasan untuk menuntut 
penggantian biaya, ganti rugi, dan bunga kepada Notaris. Sanksi ini masuk ke dalam lingkup perdata karena adanya suatu prestasi (hal yang harus dipenuhi) oleh Notaris kepada pihak/penghadap yang merasa dirugikan atas pelanggaran yang dilakukan oleh Notaris. Adanya prestasi tersebut menimbulkan suatu hubungan hukum antara Notaris dengan pihak yang menuntut ganti rugi. Hubungan hukum ini diatur oleh hukum perdata yang mewajibkan Notaris untuk melaksanakan prestasi sebagai bentuk tanggung jawab Notaris. Apabila Notaris tidak melaksanakan tanggung jawabnya, maka alasan tersebut dapat dijadikan dasar oleh pihak penghadap yang dirugikan untuk melakukan gugatan ke pengadilan, berdasarkan bukti pelanggaran yang dilakukan oleh Notaris.

\section{Tanggung Jawab Hukum Notaris secara Pidana}

Tanggung jawab hukum Notaris secara pidana adalah tanggung jawab yang harus dilaksanakan oleh Notaris apabila Notaris terbukti secara sah dan benar bahwa perbuatan Notaris dalam membuat party akta memenuhi unsur-unsur perbuatan pidana. Sanksi pidana terhadap Notaris tidak diatur di dalam UUJN, karena tugas dan fungsi jabatan Notaris pada dasarnya adalah dalam ranah hukum administrasi dan hukum perdata. Berdasar tugas dan fungsi Notaris tersebut, maka UUJN hanya memberikan sanksi berupa sanksi administratif dan sanksi perdata terhadap Notaris.

Notaris dalam menjalankan tugas jabatannya tidak menutup kemungkinan untuk dapat dikenai tanggung jawab secara pidana. Hal tersebut dapat dilihat dari unsur-unsur tindak pidana yang diatur di dalam Kitab Undang-Undang Hukum Pidana (KUHP). Sanksi yang diberikan bagi Notaris yang melakukan perbuatan pidana dalam membuat akta autentik juga merupakan sanksi pidana sebagaimana diatur di dalam KUHP, dan bukan sanksi yang diberikan oleh UUJN. Setiap pelanggaran yang dilakukan oleh Notaris, UUJN hanya memberikan sanksi berupa sanksi perdata dan sanksi administratif.

Sanksi pidana dapat diberikan kepada Notaris salah satunya adalah apabila Notaris membuka rahasia yang wajib disimpannya dalam menajalankan jabatan Notaris. Pasal 322 ayat (1) KUHP megatakan bahwa: "Barang siapa dengan sengaja membuka rahasia yang wajib disimpannya karena jabatan atau pencahariannya, baik yang sekarang maupun yang dahulu, diancam dengan pidana penjara paling lama sembilan bulan atau denda paling banyak sembilan ribu rupiah.” ketentuan tersebut sesuai dengan kewajiban Notaris untuk menyimpan rahasia terhadap seluruh informasi terhadap akta yang dibuatnya, sebagaimana diatur dalam Pasal 4 ayat (2), Pasal 16 ayat (1) furuh f, dan Pasal 54 ayat (1) UUJN.

Notaris hanya dapat bertanggung jawab secara pidana dalam perbuatan di atas apabila pihak yang merasa dirugikan, atau pihak yang bersangkutan dengan akta tersebut 
mengadukan perbuatan Notaris ke polisi atau penegak hukum lainnya (Pasal 322 ayat (2) KUHP). Delik/pidana yang terdapat pada Pasal 322 ayat (1) berdasar ketentuan Pasal 322 ayat (2) merupakan delik aduan, jadi hanya dengan adanya pengaduan dari pihak yang bersangkutan, Notaris dapat dikenai sanksi pidana. Tanggung jawab pidana lainnya juga memungkinkan untuk diberikan kepada Notaris apabila perbuatan Notaris memenuhi unsurunsur perbuatan pidana yang diatur di dalam KUHP.

\section{Perlindungan Hukum bagi Notaris dalam Membuat Party Acte}

Notaris dalam melaksanakan tugas jabatannya berhak mendapatkan perlindungan hukum dari berbagai ancaman hukum dari pihak yang hendak mempermasalahkan akta yang dibuat oleh Notaris. Perlindungan tersebut diberikan atas dasar jabatan Notaris dan kewenangan yang diberikan kepada Notaris berdasarkan undang-undang. Berdasar kelembagaan yang ada di Indonesia, Notaris secara tersirat diberikan perlindungan hukum oleh Majelis Kehormatan Notaris (MKN). MKN merupakan lembaga yang baru sama sekali, sebelum diubahnya UUJN tidak ada satu pun peraturan perundang-undangan yang membuat atau merumuskan mengenai MKN. Munculnya ketentuan mengenai MKN pada UUJN nomor 2 tahun 2014 memberikan tugas baru kepada Menteri untuk segera membuat atau merumuskan peraturan mengenai MKN. Sejak dilakukan perubahan terhadap UUJN pada tahun 2014, baru pada tahun 2016 Menteri mengeluarkan Peraturan mengenai MKN. Berdasar fakta tersebut, maka frasa “...dengan persetujuan majelis kehormatan Notaris..." yang terdapat pada Pasal 66 ayat (1) Undang-Undang Nomor 2 Tahun 2014 hingga tanggal 3 Februari 2016 merupakan 'pasal banci' yang artinya tidak dapat dilaksanakan. Pasal tersebut tidak dapat dilaksanakan karena belum dibentuknya MKN dan belum ada peraturan yang mengatur mengenai MKN. Ketentuan tersebut baru dapat dilaksanakan setelah dirumuskannya peraturan Menteri mengenai MKN pada 3 Februari 2016. Dapat dikatakan sejak tahun 2012 setelah adanya putusan MK Nomor 49/PUU-X/2012 hingga tanggal 3 Februari 2016 terdapat kekosongan perlindungan hukum bagi Notaris karena tidak ada satu pun lembaga/badan yang secara efektif memberikan perlindungan hukum kepada Notaris.

Peraturan Menteri Hukum dan Hak Asasi Manusia Nomor 7 Tahun 2016 tentang Majelis Kehormatan Notaris merupakan implementasi dari Pasal 66 ayat (1) UUJN. Majelis Kehormatan Notaris (MKN) menurut Pasal 1 angka 1 adalah suatu badan yang mempunyai kewenangan untuk melaksanakan pembinaan Notaris dan kewajiban untuk memberikan persetujuan atau penolakan untuk kepentingan penyidikan dan proses peradilan, atas pengambilan fotokopi Minuta Akta dan pemanggilan Notaris untuk hadir dalam 


\section{Lx Renaissance No. 1 VOL. 2 JANUARI 2017: 162 - 176}

pemeriksaan yang berkaitan dengan Akta atau Protokol Notaris yang berada dalam penyimpanan Notaris. Definisi mengenai MKN menurut Peraturan Menteri ini menunjukkan pelaksaan dari Pasal 66 ayat (1) UUJN. MKN terdiri atas MKN Pusat yang dibentuk oleh Menteri dan berkedudukan di ibukota Negara Republik Indonesia dan MKN Wilayah yang dibentuk oleh Direktur Jenderal atas nama Menteri dan berkedudukan di ibukota Provinsi ${ }^{8}$.

Tugas dan fungsi MKN Pusat dan MKN Wilayah berbeda. MKN Pusat menurut Pasal 17 ayat (1) dan ayat (2) mempunyai tugas melaksanakan pembinaan dan pengawasan terhadap MKN Wilayah yang berkaitan dengan tugas MKN Wilayah. Tugas MKN Pusat tidak secara langsung memberikan perlindungan hukum terhadap Notaris dalam hal penolakan atau persetujuan pemeriksaan dalam proses peradilan, melainkan melakukan pembinaan dan pengawasan terhadap pelaksanaan tugas MKN Wilayah. Dapat dikatakan, yang memberikan perlindungan hukum secara langsung kepada Notaris berupa persetujuan atau penolakan pemeriksaan akta Notaris dan Notaris dalam proses peradilan adalah MKN Wilayah ${ }^{9}$.

MKN Wilayah menurut Pasal 18 selain mempunyai tugas untuk memberikan perlindungan hukum kepada Notaris juga mempunyai fungsi untuk melakukan pembinaan terkait martabat dan kehormatan Notaris serta memberikan perlindungan kepada Notaris terkait dengan kewajiban Notaris untuk merahasiakan isi akta (kewajiban ingkar Notaris). MKN Wilayah juga diberikan kewenangan oleh Peraturan Menteri dalam Pasal 20 terkait dengan tugas dan fungsinya sebagai implementasi dari Pasal 66 UUJN. Kewenangan tersebut memberikan akibat tanggung jawab bagi MKN untuk melaksanakan tugasnya secara baik dan nyata dalam memberikan perlindungan hukum kepada Notaris. MKN juga diberikan kewenangan untuk dapat mendampingi Notaris dalam proses pemeriksaan di hadapan penyidik ${ }^{10}$. Notaris dalam hal ini sebagai jabatan yang mulia (nobile officum) dapat melaksanakan tugas jabatannya dengan aman dan tidak dapat dibawa ke pengadilan tanpa persetujuan oleh MKN. Berdasar ketentuan tersebut, bukan berarti Notaris kebal hukum, akan tetapi Notaris wajib melaksanakan tugas jabatannya dengan penuh tanggung jawab dan mempunyai konsekuensi sanksi bagi tiap-tiap pelanggaran yang dilakukannya, baik sanksi yang diberikan oleh UUJN maupun sanksi yang diberikan oleh Kode Etik Notaris. Notaris

8 Pasal 2 Peraturan Menteri Hukum dan Hak Asasi Manusia Nomor 7 Tahun 2016 tentang Majelis Kehormatan Notaris.

${ }_{9}$ Pasal 18 ayat $(1), \ldots$ ibid.

10 Pasal 27 ayat (2), ... ibid. 
yang melaksanakan jabatannya dengan tanggung jawab dan sesuai dengan UUJN serta Kode Etik Notaris adalah Notarsi yang berhak mendapat perlindungan hukum.

Notaris selain mendapat perlindungan hukum dari MKN sebagai lembaga yang ditunjuk oleh undang-undang untuk memberikan persetujuan kepada penyidik, jaksa dan hakim terkait pemanggilan Notaris atau protokol Notaris ke proses peradilan, juga mendapat perlindungan oleh hukum berdasarkan jabatannya. Notaris diberikan kewajiban/hak ingkar oleh undang-undang, yaitu kewajiban untuk merahasiakan segala isi akta yang dibuat para pihak di hadapan Notaris. Kewajiban tersebut memberikan celah perlindungan bagi Notaris untuk tetap menjaga kerahasiaan akta yang dibuat oleh atau di hadapan Notaris agar tidak serta merta dibuka dalam proses peradilan, kecuali para pihak menghendaki akta tersebut sebagai alat bukti dalam sengketa yang dihadapi oleh para pihak.

Perlindungan hukum oleh undang-undang terhadap akta Notaris terkait dengan kewajiban/hak ingkar Notaris dapat ditemukan dalam ketentuan-ketentuan sebagai berikut:

\section{Undang-Undang Nomor 2 Tahun 2014 tentang Perubahan atas Undang-Undang Nomor 30 Tahun 2004 tentang Jabatan Notaris.}

Pasal 4 ayat (2):

....."Saya bersumpah/berjanji:

.....bahwa saya akan merahasiakan isi akta dan keterangan yang diperoleh dalam pelaksanaan jabatan saya....."

Pasal 16 ayat (1):

"Dalam menjalankan jabatannya, Notaris wajib:

f. Merahasiakan segala sesuatu mengenai Akta yang dibuatnya dan segala keterangan yang diperoleh guna pembuatan Akta sesuai dengan sumpah/janji jabatan, kecuali undang-undang menentukan lain."

Pasal 54 ayat (1):

"Notaris hanya dapat memberikan, memperlihatkan, atau memberitahukan isi Akta, Grosse Akta, Salinan Akta atau Kutipan Akta, kepada orang yang berkepentingan langsung pada Akta, ahli waris, atau orang yang memperoleh hak, kecuali ditentukan lain oleh peraturan perundang-undangan.

\section{Pasal 1909 Kitab Undang-Undang Hukum Perdata (Burgerlijk Wetboek) dan Pasal 146 HIR.}

"Semua orang yang cakap menjadi saksi, wajib memberikan kesaksian di muka Hakim. Namun dapatlah meminta dibebaskan dari kewajiban memberikan kesaksian; ......3. siapa saja yang karena kedudukannya, pekerjaannya atau jabatannya diwajibkan oleh undang-undang untuk merhasiakan sesuatu, namun hanya mengenai hal-hal yang dipercayakan kepadanya karena kedudukan, pekerjaan dan jabatannya itu."

a. Pasal 170 ayat (1) Kitab Undang-Undang Hukum Acara Pidana.

"Mereka yang karena pekerjaan, harkat martabat atau jabatannya diwajibkan menyimpan rahasia, dapat minta dibebaskan dari kewajiban untuk memberi keterangan sebagai saksi, yaitu tentang hal yang dipercayakan kepada mereka." 
b. Pasal 322 Kitab Undang-Undang Hukum Pidana (Wetboek van Strafrect).

"(1) Barang siapa dengan sengaja membuka rahasia yang wajib disimpannya karena jabatan atau pencahariannya, baik yang sekarang maupun yang dahulu, diancam dengan pidana penjara paling lama sembilan bulan atau denda paling banyak sembilan ribu rupiah.

(2) Jika kejahatan dilakukan terhadap seorang tertentu, maka perbuatan itu hanya dapat dituntut atas pengaduan orang itu."

c. Pasal 89 ayat (1) huruf b Undang-Undang Nomor 51 Tahun 2009 tentang Perubahan Kedua atas Undang-Undang Nomor 9 Tahun 2004 tentang Perubahan atas UndangUndang Nomor 5 Tahun 1986 tentang Peradilan Tata Usaha Negara.

"Orang yang dapat meminta pengunduran diri dari kewajiban untuk memberikan kesaksian ialah: .......b. setiap orang yang karena martabat, pekerjaan atau jabatannya diwajibkan merahasiakan segala sesuatu yang berhubungan dengan martabat, pekerjaan atau jabatannya itu.

Ketentuan mengenai kewajiban Notaris dalam merahasiakan akta yang dibuatnya dikenal dengan istilah "hak ingkar/kewajiban ingkar Notaris". Berdasar ketentuan tersebut, Notaris wajib merahasiakan isi dan informasi mengenai akta yang dibuatnya. Akta Notaris berisi kehendak para pihak yang menghadap kepada Notaris, oleh karena itu segala hal yang berkaitan dengan akta tersebut merupakan hak dan kepentingan para pihak, sehingga undang-undang melindungi hak tersebut. Kewajiban ingkar Notaris merupakan salah satu upaya untuk melindungi kepentingan para pihak terkait akta yang dibuat di hadapan Notaris. Kewajiban Notaris untuk menjaga kerahasiaan akta yang dibuatnya dan akta yang dibuat di hadapannya merupakan kewajiban yang harus dilaksanakan, bahkan menurut Pasal 322 KUHP Notaris dapat dijatuhi pidana atas pelanggaran tidak merahasiakan akta yang dibuatnya. Para pihak yang menghadap kepada Notaris untuk membuat akta, apabila informasi atau isi mengenai akta dibuat oleh Notaris dengan melanggar kewajibannya, dan terdapat kerugian bagi para pihak, maka para pihak dapat menggugat ganti rugi dan bunga terhadap Notaris. Menurut ketentuan Pasal 16 ayat (11) UUJN, Notaris yang melanggar ketentuan untuk merahasiakan akta, dapat dikenai sanksi berupa: peringatan tertulis, pemberhentian sementara, pemberhentian dengan hormat, dan pemberhentian dengan tidak hormat dari jabatan Notaris.

\section{Penutup}

Berdasarkan pemaparan di atas maka dapat disimpulkan bahwa pertama, pertanggungjawaban hukum oleh Notaris dalam membuat party acte erat kaitannya dengan kewajiban dan sanksi yang diberikan kepada Notaris. Notaris berwenang untuk membuat akta autentik sebagaimana diatur dalam Pasal 15 UUJN. Notaris dalam melaksanakan kewenangannya tersebut mempunyai kewajiban yang harus dilakukan sebagaimana diatur 
dalam Pasal 16 UUJN. Pasal 16 UUJN juga mengatur mengenai ketentuan sanksi bagi Notaris yang tidak melaksanakan kewajibannya. Notaris dalam membuat party acte harus sesuai dengan ketentuan sebagaimana tercantum di dalam Bab VII UUJN mengenai Akta Autentik. Pelanggaran atau tidak dipenuhinya ketentuan dalam pasal-pasal mengenai akta autentik tersebut mengakibatkan sanksi bagi Notaris dan tanggung jawab Notaris dalam hukum perdata. Kewajiban dan sanksi merupakan tanggung jawab hukum yang diberikan kepada Notaris. Berdasar kewajiban dan sanksi tersebut, Notaris mempunyai pertanggungjawaban hukum dalam membuat party acte berupa: tanggung jawab administrasi, tanggung jawab perdata dan tanggung jawab pidana.

Kedua, Perlindungan hukum bagi Notaris dalam membuat party acte dapat diperoleh dari 2 (dua) elemen, yaitu dari Majelis Kehormatan Notaris (MKN) dan peraturan perundang-undang yang berlaku. MKN dibentuk atas dasar perintah UUJN dalam Pasal 66 ayat (1) yang memberikan aturan bahwa penyidik, penuntut umum dan hakim harus melalui persetujuan MKN apabila hendak membawa akta Notaris dan/atau Notaris dalam proses peradilan. Perintah UUJN yang memuat frasa “...dengan persetujuan majelis kehormatan Notaris..." dapat diartikan sebagai upaya perlindungan hukum terhadap pejabat Notaris.

MKN harus memeriksa Notaris dan akta autentik bersangkutan yang dimohonkan oleh penyidik, penuntut umum dan hakim untuk keperluan proses peradilan, sehingga berdasar kewenangan MKN tersebut, penyidik, penuntut umum dan hakim tidak dapat berbuat sewenang-wenang untuk menghadirkan Notaris maupun akta Notaris dalam proses persidangan. Undang-undang juga memberikan perlindungan terhadap Notaris, akta Notaris dan sifat privat dari kepentingan para pihak yang menghadap kepada Notaris, yaitu dengan istilah yang dikenal dengan hak ingkar/kewajiban ingkar Notaris. ketentuan tersebut diatur di dalam Pasal 4 ayat (2), Pasal 16 ayat (1) huruf f dan Pasal 54 ayat (1) UUJN, Pasal 1909 KUH Perdata dan Pasal 146 HIR, Pasal 170 ayat (1) KUHAP, Pasal 322 KUHP, dan Pasal 89 ayat (1) huruf b Undang-Undang Nomor 51 Tahun 2009 tentang Perubahan Kedua atas Undang-Undang Nomor 9 Tahun 2004 tentang Perubahan atas Undang-Undang Nomor 5 Tahun 1989 tentang Peradilan Tata Usaha Negara.

Hak/kewajiban ingkar Notaris ini merupakan kewajiban Notaris untuk merahasiakan isi akta dan keterangan yang diperoleh dalam pelaksanaan jabatan Notaris, dan Notaris juga berhak untuk mengundurkan diri dari kedudukannya sebagai saksi dalam persidangan atas dasar merahasiakan isi akta dan keterangan yang diperoleh dalam pelaksanaan jabatan Notaris. hak.kewajiban ingkar ini merupakan upaya perlindungan hukum dari undang- 
undang kepada Notaris demi menjaga kewibawaan dan kerahasiaan akta yang diberisi kehendak/kepentingan para pihak yang menghadap kepada Notaris.

\section{Daftar Pustaka}

Sjaifurrachman, Aspek Pertanggungjawaban Notaris dalam Pembuatan Akta, Bandung: Mandar Maju, 2011.

M. Marwan \& jimmy P., Kamus Hukum (Dictionary of Law Complete Edition), Cetakan Kesatu, Surabaya: Reality Pulisher, 2009.

Munir Fuady, Profesi Mulia (Etika Profesi Hukum bagi Hakim, Jaksa, Advokat, Notaris, Kurator, dan Pengurus), Cetakan Pertama, Bandung: PT. Citra Aditya Bakti, 2005.

Hans Kelsen, Pure Theory of Law, Terjemah, Raisul Muttaqien, Teori Hukum Murni: Dasar-Dasar Ilmu Hukum Normatif, Cetakan Keenam, Bandung: Penerbit Nusa Media, 2008.

Habib Adjie, Sanksi Perdata dan Administratif terhadap Notaris sebagai Pejabat Publik, Cetakan Kedua, Bandung: Refika Aditama, 2009. 